\title{
Tinkamo vaistų derinio ir tinkamo inhaliatoriaus parinkimo svarba gydant lètinę obstrukcinę plaučių ligą
}

\author{
THE IMPORTANCE OF CHOOSING THE RIGHT DRUG AND RIGHT INHALER DEVICE \\ IN CHRONIC OBSTRUCTIVE PULMONARY DISEASE
}

\author{
LAIMA KONDRATAVIČIENE் \\ LSMU MA Pulmonologijos klinika
}

\begin{abstract}
Santrauka. Lètinès obstrukcinės plaučių ligos medikamentinio gydymo pagrindas yra įkvepiamieji bronchus plečiantieji vaistai. Atlikti klinikiniai tyrimai įrodè, kad ịkvepiamieji ilgo veikimo muskarino receptorių blokatoriai (IVMB) ir ilgo veikimo $\beta_{2}$ agonistai (IVBA), derinami kartu, yra veiksmingesni nei įprasti trumpo veikimo vaistai, o jų farmakologiniai profiliai veiksmingai vienas kitą papildo. Tačiau be veiksmingo vaistų derinio labai svarbus ir tinkamo inhaliatoriaus parinkimas. Respimat ${ }^{\circledR}$ smulkią miglą formuojantis inhaliatorius - tai unikalus prietaisas, pasižymintis ypač didele vaisto dalelių depozicija net smulkiausiuose kvèpavimo takuose, palyginus su kitais prietaisais.

Reikšminiai žodžiai: lètinè obstrukcinè plaučių liga, Respimat ${ }^{\oplus}$, smulkią miglą formuojantis inhaliatorius, tiotropis, olodaterolis. Summary. The main treatment of chronic obstructive pulmonary disease is inhaled bronchodilators. Clinical trials showed and proved long-acting anti-muscarines (LAMA) and long-acting $\beta_{2}$ agonists (LABA) are both more effective than regular short-acting drugs. Complementary pharmacological profiles of tiotropium and olodaterol and data from studies of double therapy showed that these medicinal products effectively supplement each other. Combined LAMA LABA therapy increases the general therapeutic benefit. However, choosing the right inhaler is very important in addition to an effective combination of drugs. Respimat ${ }^{\circledast}$ soft mist inhaler is a unique device that delivers extremely high deposition of drug particles even in the smallest airways, compared to other devices.
\end{abstract}

Keywords: Chronic obstructive pulmonary disease, Respimat ${ }^{\oplus}$, soft mist inhaler, tiotropium, olodaterol.

\section{IVADAS}

Lètinè obstrukcinè plaučių liga (LOPL) - tai liga, pasireiškianti dèl kvėpavimo takų pažeidimo, kurią dažniausiai sukelia ịkvepiamos žalingos dalelès arba dujos, susijusios su ilgalaikiu tabako rūkymu. Šiai ligai būdingas kosulys, skrepliavimas arba oro stygius bei nuolatine bronchų obstrukcija, randama ir atliekant funkcinius kvėpavimo mėginius. Svarbiausia LOPL patogenezès grandis - kvèpavimo takų, ypač smulkiųjų, spindžio susiaurèjimas (obstrukcija) ir oro spąstai, sutrikdantys oro pasišalinimą iš plaučių, dèl to išsivysto hiperinfliacija, o esant fiziniam krūviui, mažèja ¡̇kvépimo talpa, kuri sukelia dusulị bei riboja fizinị krūvị [1]. Pacientui itin svarbu parinkti ne tik adekvatų medikamentinị gydymą, bet ir jam tinkamiausią inhaliatorių, užtikrinantị veiksmingą vaisto patekimą i obstrukcijos vietą.

\section{STABILIOS LOPL GYDYMO PRINCIPAI}

Svarbiausi LOPL gydymo uždaviniai yra skirtingi ir individualūs kiekvienam pacientui, atsižvelgiant ì jo būklę, tačiau esminiai išskiriami šie: metimas rūkyti (bei kitų rizikos veiksnių šalinimas), bronchų laidumo gerinimas ir bronchų sekreto šalinimo užtikrinimas, kvėpavimo nepakankamumo korekcija (siekiant mažinti hipoksemiją ir hiperkapniją), fizinio aktyvumo didinimas bei kvèpavimo takų uždegiminių ligu prevencija. Pagrindinès vaistų grupès, skirtos stabiliai LOPL gydyti: ilgo veikimo muskarino receptorių blokatoriai (IVMB), ilgo veikimo $\beta_{2}$ agonistai (IVBA) bei ¡kvepiamieji gliukokortikoidai (IGK) [2].

Pagrindine farmakologinė vaistų grupe LOPL gydyti, rekomenduojama ir Pasaulinès lètinès obstrukcinès plaučių ligos iniciatyvos (angl. Global Initiative for Chronic Obstructive Lung Disease, GOLD), yra bronchus plečiantieji vaistai [3]. Pagal LOPL gydymo rekomendacijas, trumpo veikimo $\beta_{2}$ agonistai, IVBA, IVMB, vartojami dusulio priepuolio metu arba pastoviai, pagerina plaučių funkciją ir sumažina dusulį, tačiau, vartojant IVBA ir IVMB derinị, nustatytas geresnis poveikis: veiksmingesni bei patogesni vartoti nei ịprasti vienkomponenčiai vaistiniai preparatai. Ilgo veikimo bronchus plečiantieji vaistai sumažina bronchų obstrukciją ir dusulį, taip pagerindami fizinio krūvio toleranciją, gyvenimo kokybę bei mažindami paūmejjimų riziką. IGK poveikis gali būti veiksmingas, kai yra nustatytas astmos - LOPL persidengimo fenomenas, t. y., esant dažniems neinfekcinès kilmès 


\section{Farmakoterapija}

paūmejjimams ir padidejusiam eozinofilų skaičiui. Tačiau pirmojo pasirinkimo vaistai turètų būti ilgo veikimo bronchus plečiantieji vaistai.

Remiantis Lietuvos pulmonologų sutarimu, rekomenduojamas pakopinis LOPL gydymas, atsižvelgiant ¿̇ LOPL stadiją, kuri nustatoma pagal forsuoto iškvejpimo tūrị per pirmąją sekundę (angl. forced expiratory volume in 1 sec., $\mathrm{FEV}_{1}$ ). Tad, atsižvelgiant $i$ tai, LOPL gydymas pradedamas ịkvepiamuoju bronchus plečiančiuoju vaistu. Kokị vaistą iš bronchus plečiančiujuu parinkti pacientui, yra individualu: jei yra dažnesni LOPL paūmejjimai, rekomenduojama ir teikiamas prioritetas IVMB, o vyraujant oro stygiui, sunkumui krūtineje arba dusuliui - IVBA. Esant nepakankamam gydymo poveikiui (esant išreikštiems LOPL simptomams), svarstoma galimybė rinktis kompleksini gydymą IVMB/IVBA deriniu. Tačiau svarbu atsižvelgti, kad veiksmingam LOPL gydymui svarbu ne tik tinkamas vaisto, bet ir inhaliatoriaus parinkimas bei taisyklingas jo naudojimas. Tai pagrindiniai aspektai, siekiant geros klinikinès ligos kontrolès bei gyvenimo kokybès pagerinimo [4].

\section{TIOTROPIO BROMIDAS IR OLODATEROLIS}

Tiotropio bromidas jau ilgą laiką yra vienas iš svarbiausių vaistų LOPL gydyti. Jis buvo pirmasis IVMB grupès vaistas, patvirtintas LOPL gydymui palaikyti. Tiotropio bromidas turi dvi skyrimo formas: Respimat ${ }^{\circ}$ išpurškiamo tirpalo per smulkią miglą formuojantị inhaliatorių (angl. soft mist inhaler, SMI) arba HandiHaler inhaliatorių - sausųjų miltelių pavidalo. Abiem formomis vaistas vartojamas vieną kartą per parą. Tiotropio bromido veiksmingumą, skiriant vieną kartą per parą, užtikrina jo ilgesnis pusinès eliminacijos laikas, palyginus su kitais IVMB (27-45 val. po inhaliacijos, kai tuo tarpu aklidinio pusinès eliminacijos laikas - tik 2-3 val.).

Olodaterolis - IVBA grupès vaistas, veikiantis 24 val. bei pasižymintis selektyviu poveikiu $\beta_{2}$ adrenoreceptoriams. Po ¡kvejpimo jis prisijungia prie $\beta_{2}$ receptoriu ir juos aktyvina, nes stimuliuojama viduląstelinè adenilatciklazè (ciklinio 3,5 adenozinmonofosfato (cAMP) sintezès tarpininko fermentas). Padidejusi cAMP koncentracija atpalaiduoja kvépavimo takų lygiưjų raumenų ląsteles ir išplečia bronchus. Olodaterolio poveikis prasideda iškart ir tęsiasi ne trumpiau nei 24 val. Jo metabolizmas vyksta per kepenis, o metabolitai išskiriami su išmatomis (palyginus su tiotropiu, kurio metabolitai šalinami per inkstus). Esant inkstų nepakankamumui, dozès korekcija nenurodyta, tačiau rekomenduojama, kad pacientams, kuriems yra sunkus inkstų pažeidimas, tiotriopis arba tiotropio su olodateroliu derinys turètų būti skiriamas atidžiau.

Taigi, kaip apžvelgta aukščiau, IVMB ir IVBA grupių vaistai veikia per skirtingus mechanizmus, tačiau, vartojami kartu, jie stiprina bronchus plečiantijji poveiki. Siekiant ištirti gydymo tiotropio ir olodaterolio deriniu per Respimat ${ }^{\oplus}$ inhaliatorių poveiki, palyginus su vienkomponenčiais vaistiniais preparatais (tiotropiu arba olodateroliu), buvo parengta išplèstinè klinikinių tyrimų programa ToviTO. Šių tyrimų pagrindinis tikslas - įrodyti, kad dviejų vaistų derinys viename inhaliatoriuje yra patogesnis vartoti, padidina vaisto dalelių patekimą į smulkiuosius kvejpavimo takus, taip su mažesne vaisto doze pasiekiant geriausią gydymo poveikị (ypač naudojant smulkią miglą formuojantị inhaliatorių Respimat ${ }^{\oplus}$ ). Šioje programoje dalyvavo daugiau nei 16 tūkst. pacientų, sergančių vidutinio sunkumo ir sunkia LOPL, iš daugiau nei 50 šalių.

\section{TIOTROPIO SU OLODATEROLIU VEIKSMINGUMAS IR SAUGUMO IVERTINIMAS KLINIKINIUOSE TYRIMUOSE}

Pirmuoju ToviTO programos klinikiniu tyrimu VIVACITO siekta ịvertinti 24 val. kvejpavimo funkciją asmenims, sergantiems LOPL ir vartojantiems tiotropio su olodateroliu derinị per Respimat ${ }^{\oplus}$ inhaliatorių. Šio tyrimo pagrindinis tikslas - ivertinti $\mathrm{FEV}_{1}$ plotą po kreive (angl. Area Under the Curve) nuo 0 iki 24 val. (FEV ${ }_{1}$ AUC 0-24 val.). Tiotropio ir olodaterolio 5/5 $\mu \mathrm{g}$ derinys reikšmingai padidino $\mathrm{FEV}_{1}$ AUC 0-24 val., palyginus su monoterapija tiotropiu $5 \mu \mathrm{g}$ bei olodateroliu $5 \mu \mathrm{g}$ (atitinkamai $-110 \mathrm{ml}$ palyginus su tiotropiu $5 \mu \mathrm{g}$, $\mathrm{p}<0,0001,115 \mathrm{ml}$ - su olodateroliu $5 \mu \mathrm{g}, \mathrm{p}<0,0001$ ir net $280 \mathrm{ml}$ - su placebu, $\mathrm{p}<0,0001)$ (1 pav.) [5].

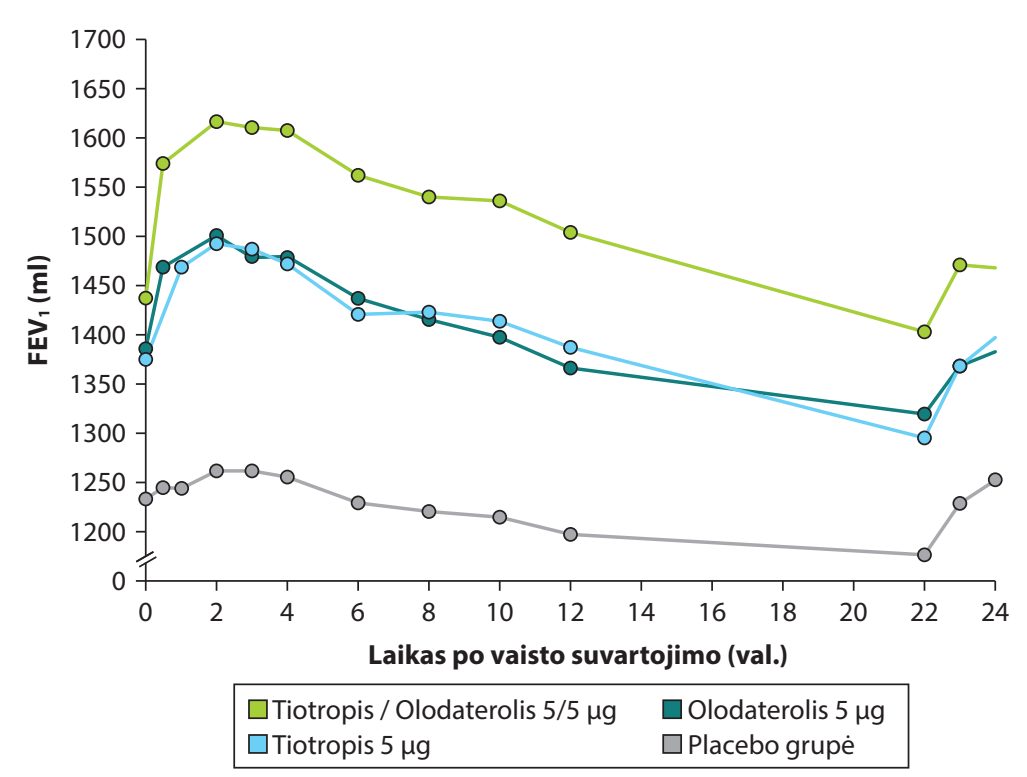

1 pav. VIVACITO klinikinis tyrimas. FEV $_{1}$ atsakas, vertintas praejjus 24 val. po vaisto suvartojimo

Santrumpos: $\mathrm{FEV}_{1}$ - forsuoto iškvèpimo tūris per pirmają sekundę. 


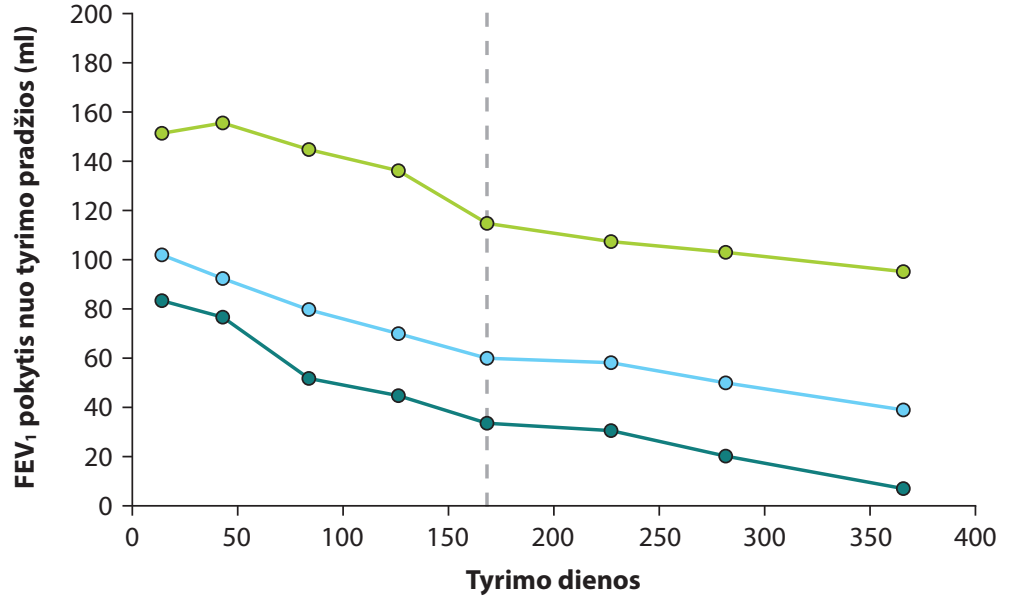

$\square$ Tiotropis / Olodaterolis $5 / 5 \mu \mathrm{g} \quad \square$ Tiotropis $5 \mu \mathrm{g} \quad \square$ Olodaterolis $5 \mu \mathrm{g}$

2 pav. TONADO klinikinis tyrimas. $\mathrm{FEV}_{1}$ pokytis nuo tyrimo pradžios per 52 savaičių gydymo laikotarpi

Santrumpos: $\mathrm{FEV}_{1}$ - forsuoto iškvėpimo tūris per pirmają sekundę.


$\square$ Tiotropis / Olodaterolis $5 / 5 \mu \mathrm{g} \quad \square$ Tiotropis $5 \mu \mathrm{g} \quad \square$ Olodaterolis $5 \mu \mathrm{g}$

3 pav. SGRQ bendrojo balo pokytis ir procentinis respondentų skaičius po 24 savaičių

Santrumpos: SGRQ - Šv. Jurgio ligoninès kvèpavimo klausimyno (angl. Saint George's Respiratory Questionnaire).

Vienas iš skaitlingiausių ToviTO programos klinikinių tyrimu TONADO ịrode, kad, palyginus su vienkomponenčiais preparatais, tiotropis su olodateroliu užtikrina ilgalaikị ir reikšmingą plaučių funkcijos pagerejimą. Tiotropio ir olodaterolio fiksuotų dozių derinys reikšmingai pagerino mažiausio $\mathrm{FEV}_{1}$ (angl. trough $F E V_{1}$ - reikšmių vidurkis atlikus matavimus 1 val. ir 10 min. prieš pirmają tiriamo preparato dozę ir tyrimo pabaigoje) pokytị nuo tyrimo pradžios praejus 24 sav., palyginus su vienkomponenčiais vaistiniais preparatais dviejuose pakartotiniuose tyrimuose (tiotropio ir olodaterolio $5 / 5 \mu \mathrm{g}$ derinio grupeje $(136 \mathrm{ml})$, palyginus su tiotropiu $5 \mu \mathrm{g}(65 \mathrm{ml})$ ir olodateroliu $5 \mu \mathrm{g}$ (54 ml); abiem atvejais $\mathrm{p}<0,0001$ ), šis poveikis buvo ilgalaikis ir išliko visą 52 savaičių tyrimo laikotarpi (2 pav.) [6].
Siekiant sužinoti, kaip minèti pokyčiai veikia paciento savijautą, ar jis jaučia pagerẻjimą, šiuose klinikiniuose tyrimuose buvo vertinamas Šv. Jurgio kvèpavimo klausimynas (angl. St. George's Respiratory Questionnaire, SGRQ) po 24 sav. gydymo. Atlikus analizę, paaiškejjo, kad tiotropio ir olodaterolio 5/5 $\mu \mathrm{g}$ (SGRQ 6,8 b.) grupëje pagerejjimas buvo reikšmingai didesnis nei asmenu, gydomų vien tiotropiu $5 \mu \mathrm{g}$ (SGRQ 5,6 b.) arba vien olodateroliu $5 \mu \mathrm{g}$ (SGRQ 5,1 b.), palyginus su duomenimis tyrimo pradžioje. Skirtumai tarp gydymo tiotropio ir olodaterolio $5 / 5 \mu \mathrm{g}$ deriniu bei gydymo vienkomponenčiais vaistiniais preparatais, skiriant juos atskirai, buvo statistiškai reikšmingi (kiekvienu atveju $\mathrm{p}<0,05)$ (3 pav.).

Su fizine veikla susijęs hiperinfliacijos sukeltas dusulys - vienas būdingiausiu LOPL sutrikimų, ribojantis fizinio krūvio toleranciją, kasdienę veiklą, o svarbiausia - bloginantis gyvenimo kokybę. Kitu TOviTO programos klinikiniu tyrimu MORACTO siekta ištirti tiotropio ir olodaterolio derinio veiksmingumą plaučiu hiperinfliacijai, matuojant įkvépimo talpą prieš ir po fizinio krūvio bei vertinant krūvio tolerancijos pokyčius, palyginus su placebu ir vienkomponenčiais vaistiniais preparatais po šešių savaičių gydymo. Tiotropio ir olodaterolio derinys sumažina plaučių hiperinfliaciją, palyginus tiek su tiotropiu, tiek su olodateroliu arba placebu, bei padidina fizinio krūvio toleranciją (4 pav.) [7].

Vienas svarbiausių veiksnių, galinčių sukelti reikšmingą plaučių funkcijos pablogèjimą sergantiesiems LOPL, yra paūmèjimai. Jie blogina LOPL sergančiojo gyvenimo kokybę, spartina plaučiu funkcijos blogèjimą, emfizemos progresavimą, didina hospitalizacijos dažnį ir mirštamumą [2]. Tyrimai taip pat rodo, kad, pasibaigus ligos paūmejjimui, daliai ligonių plaučių funkcija ir sveikatos būklè negrịžta ị pradinị lygị, o po antro sunkaus paūmejjimo dažniausiai sparčiai blogeja. Todèl svarbi vaistinio preparato charakteristika - paūmejjimų riziką mažinantis poveikis. Daugeliu ankstesnių klinikinių tyrimų buvo įrodyta, kad tiotropis - itin veiksmingas mažinant vidutinio sunkumo ir sunkių LOPL paūmejjimų riziką, pvz., INVIGORATE klinikiniame tyrime buvo įrodytas geresnis tiotropio poveikis metiniam paūmèjimu skaičiui, palyginus su indakateroliu (tiotropio grupejje vidutiniškai sunkių ir sunkių paūmèjimų 


\section{Farmakoterapija}

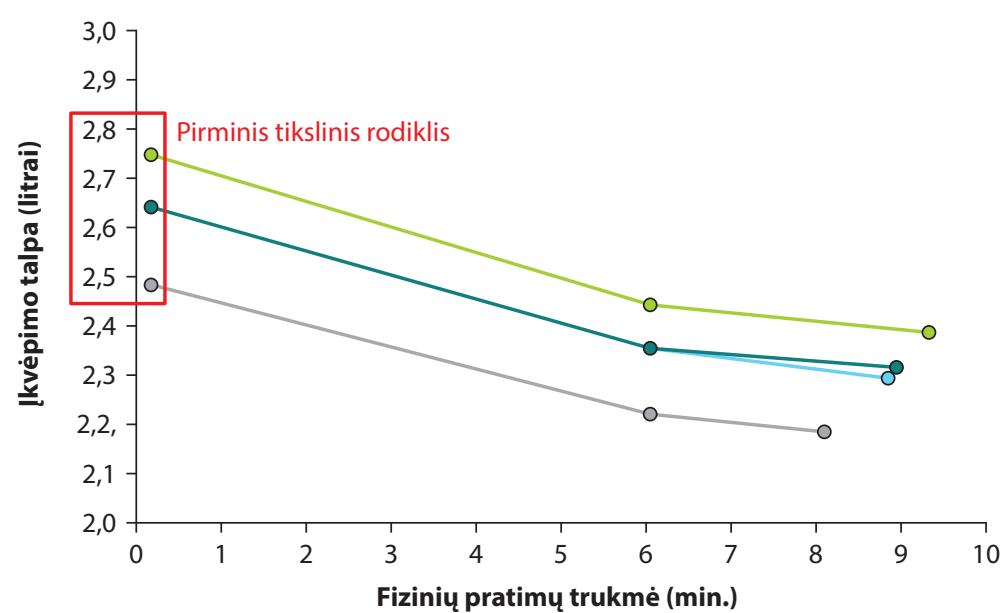

\begin{tabular}{ll|}
$\square$ Tiotropis / Olodaterolis 5/5 $\mu \mathrm{g}(\mathrm{n}=437)^{*}$ & $\square$ Olodaterolis $5 \mu \mathrm{g}(\mathrm{n}=422)$ \\
$\square$ Tiotropis $5 \mu \mathrm{g}(\mathrm{n}=421)$ & $\square$ Placebo grupe $(\mathrm{n}=413)$
\end{tabular}

4 pav. MORACTO klinikinis tyrimas. Fizinio krūvio tolerancija, skiriant tiotropio ir olodaterolio derinį bei vienkomponenčius vaistinius preparatus

dažnis per 52 savaites buvo 0,61 , o olodaterolio grupéje - 0,79, tai yra net 29 proc. daugiau paūmèjimų, $\mathrm{p}<0,0001)$; taip pat SPARK tyrimo metu, gydant glikopironio / indakaterolio deriniu, nepavyko įrodyti reikšmingo paūmèjimų dažnio skirtumo, palyginus vien su tiotropiu, ir vertinant jo poveikị vidutiniams ir sunkiems (dažnio santykis (DS) - 0,90; 99 proc. pasikliautinasis intervalas (PI) $0,79-1,02 ; \mathrm{p}=0,096)$ bei sunkiems paūmejimams (DS - 1,16; 99 proc. PI $0,84-1,61 ; \mathrm{p}=0,36)$. Vykdant klinikinių tyrimų programą TOviTO, atkreiptas dèmesys į tiotropio / olodaterolio derinio veiksmingumą, mažinant paūmejjimų dažnį, palyginus su tiotropiu. Remiantis šių duomenų analize ir buvo suprojektuotas DYNAGITO klinikinis tyrimas, kuriuo buvo siekiama ivertinti tiotropio bei tioropio su olodateroliu derinio veiksmingumą pacientams, sergantiems vidutinio sunkumo arba sunkia LOPL, vertinant jų paūmèjimų dažnị. Vidutinio sunkumo ir sunkių paūmèjimų dažnis buvo 7 proc. mažesnis, gydant tiotropio / olodaterolio deriniu, palyginus su monoterapija tiotropiu (vidurkis $-0,93$; 99 proc. PI $0,85-1,02 ; \mathrm{p}=0,0498$ ), tačiau nebuvo pasiekta tikslinio 0,01 reikšmingumo lygmens pranašumui ịvertinti. Pasirinkus iprastą 95 proc. reikšmingumo lygi, nustatyti reikšmingai retesni LOPL paūmejjimai. Koreguotas ịvykių dažnio vidurkis per paciento metus tiotropio grupeje buvo 0,97 (PI 0,90-1,03), o tiotropio ir olodaterolio grupéje - 0,90 (PI 0,84-0,96) (5 pav.) [8].

Gydymo tiotropio ir olodaterolio deriniu tyrimai parode pranašumą, palyginus su gydymu vienkomponenčiais vaistiniais preparatais, gerinant plaučiu funkciją, mažinant simptomus, plaučių hiperinfliaciją, didinant fizinị aktyvumą bei retinant LOPL paūmèjimus.

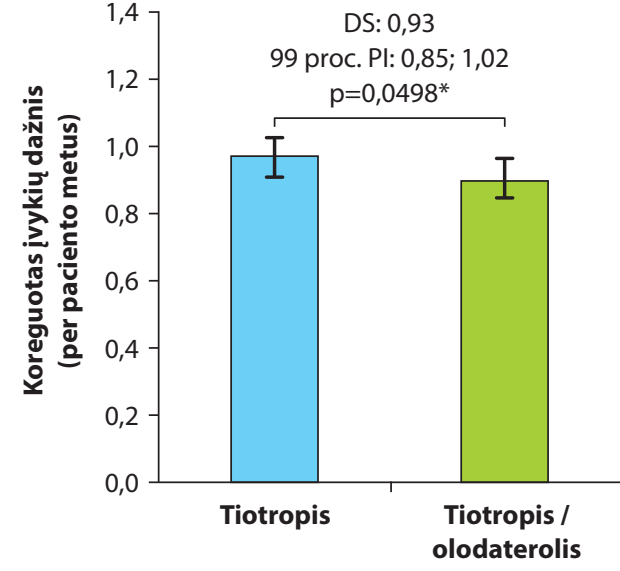

5 pav. DYNAGITO klinikinis tyrimas. Tiotriopo ir olodaterolio derinio veiksmingumas paūmèjimų dažniui

*Pirminis tikslinis rodiklis nebuvo pasiektas

Santrumpos: DS - dažnio santykis; PI - pasikliautinasis intervalas.

\section{TINKAMO INHALIATORIAUS PARINKIMO SVARBA}

Sèkmingas kvèpavimo takų ligų gydymas priklauso ir nuo vaisto patekimo it plaučius. Skirtingi inhaliatoriai pasižymi skirtingomis savybemis, turinčiomis įtakos vaisto patekimui i plaučius ir paciento pasitenkinimui dèl paprasto naudojimo, o tai gali turèti ịtakos klinikiniams LOPL gydymo rezultatams. Respimat ${ }^{\oplus}$ SMI buvo sukurtas, siekiant užtikrinti kuo didesnį vaisto dalelių patekimą i kvépavimo takus, ypač i t smulkiuosius, sumažinti paciento pastangas bei pagerinti pasitenkinimą naudojant šį inhaliatorių. Klinikiniai tyrimai lygino Respimat ${ }^{\oplus}$ SMI su Respimat ${ }^{\oplus}$ sausujjų miltelių inhaliatoriumi (angl. dry powder inhaler, DPI) bei suslègtų fiksuotų dozių inhaliatoriumi (angl. pressurized metered - dose inhaler, pMDI).

Obstrukcinèmis plaučių ligomis sergantiesiems suformuoti pakankamą vaisto ịkvépimo srovę yra gana sudètinga, todèl jiems netinka DPI inhaliatoriai. Naudojant pMDI inhaliatorių, dažna problema yra nekoordinuotas ir su ịkvépimu nesuderintas pMDI inhaliatoriaus aktyvinimas, su tuo dažnai susiduria vyresnio amžiaus pacientai. Taip pat pMDI inhaliatorių trūkumas - kad didžioji vaisto dalis nusèda burnaryklejje, o giliai ị plaučius, ypač ị smulkiuosius kvėpavimo takus, patenka tik maža vaisto dalis. SMI inhaliatorius pasižymi unikaliu veikimo mechaniz$\mathrm{mu}$, dèl kurio ore dalelès išsilaiko apie šešis kartus ilgiau, palyginus su pMDI, ir tai sąlygoja padidejusią sẻkmingo ịkvépimo galimybę, pagerèjusią vaisto depoziciją plaučiuose ir sumažéjusị nusėdimą burnoje arba ryklejje [9].

Respimat $^{\oplus}$ SMI inhaliatorius buvo sukurtas, atsižvelgiant $\mathfrak{i}$ idealaus inhaliatoriaus savybes ir poreiki turèti kišenèje telpantị prietaisą, kuris galètų generuoti vieno ịkvèpimo aerozolį. Idealaus inhaliatoriaus savy- 

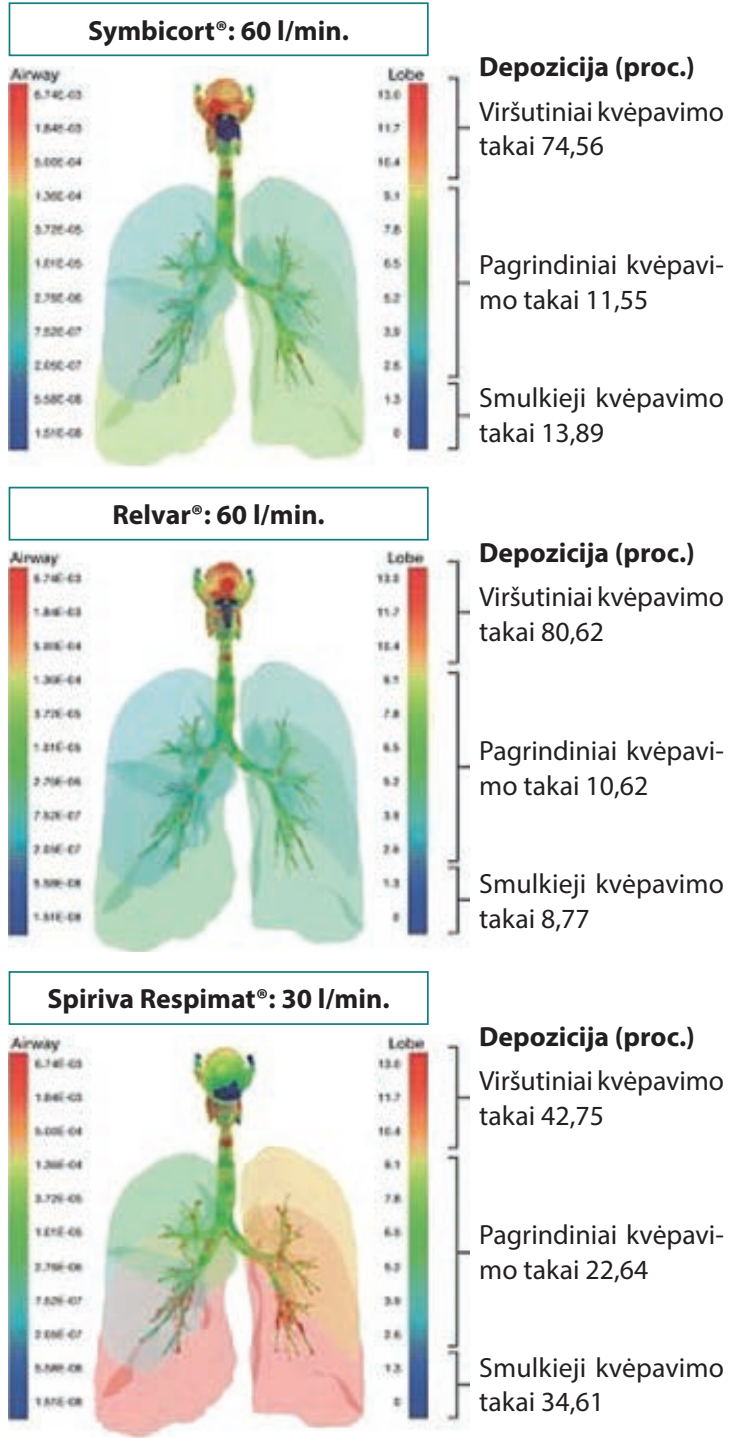

6 pav. IVMB ir IVBA dalelių depozicija kvèpavimo takuose naudojant skirtingus inhaliatorius. Paveiksle pavaizduota skirtingu vaistų, ikvepiamų per skirtingus inhaliatorius, depozicija to paties paciento plaučiuose.

Santrumpos: IVBA - ilgo veikimo $\beta_{2}$ agonistai; IVMB - ilgo veikimo muskarino receptorių blokatoriai.

Raudona spalva reiškia dideli vaisto daleliu atsidejjimą, mèlyna - labai negausų.

bès apima: vaisto nugabenimą ir įsisavinimą (didelè depozicija plaučiuose; nuo įkvèpimo srovés nepriklausomas aerozolio generavimas; didelè smulkiųjų dalelių ( $<5 \mu \mathrm{m}$ dydžio) frakcija; lètai generuojama vaisto dozè (per $>1$ sekundę); nedidelis aerozolio dalelių greitis), naudojimo patogumą (telpantis kišenèje, lengvai naudojamas, talpinantis daugiau nei 50 doziu ir turintis dozių skaitiklį) bei farmakologinių savybių užtikrinimą (neturi propelento, išskiria vienodą dozę, atsparus taršai, drègmè nekeičia įkvepiamojo vaisto savybių) [10].

Respimat ${ }^{\circ}$ SMI inhaliatorius, palyginus su MDI ir DPI, turi pranašesni vaisto depozicijos plaučiuose profili pacientams, sergantiems astma arba LOPL. Iwanaga $\mathrm{T}$. su bendraautoriais tyrimo metu, atliekant radiologinius (vaizdinius) kvejpavimo takų matavimus, buvo nustatyta, kad šešiems pacientams, sergantiems astma, naudojant Respimat ${ }^{\circledR}$ SMI, vaisto depozicija plaučiuose ir periferiniuose kvèpavimo takuose sieke atitinkamai 57,1 ir 39,7 proc. ir buvo didesnè, negu naudojant MDI arba DPI tipo inhaliatorius (atitinkamai visuose plaučiuose buvo 20,0 ir 44,3 proc.; o depozicija periferiniuose kvépavimo takuose - 11,3 ir 29,2 proc.) (6 pav.) [11].

Respimat $^{\circ}$ SMI, palyginus su MDI ir DPI, depoziciją burnaryklèje ištyrè Ciciliani AM. In vitro kompiuterinio modeliavimo tyrime buvo palyginti keturi skirtingi inhaliatoriai: Respimat ${ }^{\oplus}$, Breezhaler ${ }^{\oplus}$, Genuair ${ }^{\oplus}$ ir Ellipta ${ }^{\mathrm{m}}$. Šio tyrimo tikslas buvo palyginti aerozolio kaupimąsi burnaryklèje ir plaučiuose Respimat ${ }^{\oplus}$ ir kitų SMI atvejais. Vaisto dalelių kaupimosi dozè buvo vertinta modeliuojama doze i plaučius (angl. modeled dose to the lung, $\mathrm{mDTL}$ ). Pagrindinèse šio tyrimo išvadose teigiama, kad ị plaučius įkvepiama vaisto dozé per Respimat ${ }^{\oplus}$ inhaliatorių buvo didesnè (67 proc. \pm 5 proc.), palyginus su Breezhaler ${ }^{\ominus}$ ( 51 proc. \pm 2 proc.) arba Genuair ${ }^{\oplus}(42$ proc. \pm 1 proc.). Taip pat irodyta, kad, įkvepiant per Respimat ${ }^{\oplus}$ inhaliatorių, vaistas mažiau kaupiasi burnaryklès srityje negu per Breezhaler ${ }^{\oplus}$ arba Genuair $^{\circledR}$ inhaliatorius [12].

Hochrainer D. in vitro palyginamajame tyrime vertintas Respimat ${ }^{\oplus}$ SMI inhaliatoriaus generuojamo aerozolio greitis ir patvarumas, palyginus su hidrofluoralkano (HFA) bei chlorofluorokarbono (CFC) nešiklius turinčiais pMDI. Nustatyta, kad per Respimat $^{\oplus}$ inhaliatoriu ikvepiamo aerozolio greitis yra mažiausias, t. y. $0,8 \mathrm{~m} / \mathrm{s}$ (taip pat svarbu, kad vaisto dalelès yra išliekančios iki $1,5 \mathrm{~s}$, o smulkiujų dalelių frakcija sudaro net 75 proc. vaisto dozès), o CFC pMDI aerozolių greičiai sieké 5,6-8,3 m/s, HFA-sMDI aerozolių greičiai buvo $2,0-8,4 \mathrm{~m} / \mathrm{s}$. Ilgai kvèpavimo takuose išliekančios vaisto dalelès, nedidelis aerozolio greitis bei didelè smulkiųjų dalelių frakcija padeda užtikrinti, kad didžioji vaisto dalis su ikvejpimo srove pateks giliai ị kvejpavimo takus, o burnoje ir ryklèje nusès tik minimalus vaisto kiekis [13].

Taip pat svarbu paminèti, kad Respimat ${ }^{\oplus}$ inhaliatoriaus privalumas yra aplinkos taršos mažinimas. Tai užtikrina naujos kartos inhaliatoriaus prietaisas, turèdamas galimybę naudoti tą patị inhaliatoriu šešis kartus ilgiau (keičiant užtaisus). Vienkartinio naudojimo Respimat $^{\oplus}$, kuris neturi propelento, anglies junginių emisija yra 20 kartų mažesnè nei daugumos pMDI. O naujo kartotinio naudojimo Respimat ${ }^{\oplus}$ inhaliatoriaus anglies junginiu emisija yra dar 50-63 proc. mažesnè už vienkartinio naudojimo Respimat ${ }^{\circ}$ ir net iki 98,5 proc. mažesnè, palyginus su pMDI. Atsižvelgiant i LOPL sergančiujų skaičių, statistika dar reikšmingesnè. Jei kiekvienas LOPL sergantysis gydymui naudotų kartotinio naudojimo Respimat ${ }^{\oplus}$ inhaliatorių šešis mèn., 


\section{Farmakoterapija}

tai padètų sutaupyti $2,51 \mathrm{mlrd}$. inhaliatorių ir leistų sumažinti $\mathrm{CO}_{2}$ emisiją daugiau nei $17,5 \mathrm{mln}$. tonų [14].

\section{IŠVADOS}

Pacientams, sergantiems vidutinio sunkumo arba sunkia LOPL, svarbiausia parinkti ne tik tinkamą vaistą arba jo derini, bet ir tinkamą inhaliatorių, išmokyti juo naudotis bei nuolat kontroliuoti inhaliavimo techniką. Respimat $^{\oplus}$ - smulkią, patvarią ir lètai judančią miglą formuojantis inhaliatorius, užtikrinantis itin didelę vaisto dalelių depoziciją net pačiuose smulkiausiuose kvėpavimo takuose (LOPL - smulkiųjų kvėpavimo takų liga), ypač tinka pacientams, kurių ịkvėpimo srovė maža, o ịkvėpimo koordinacija - bloga. Klinikiniais tyrimais įrodyta, kad tiotropio ir olodaterolio derinys greitai ir patikimai padidina bronchų laidumą, pagerina simptomų kontrolę, fizinio krūvio toleranciją, sumažina hiperinfliaciją ir paūmèjimų riziką bei reikšmingai prisideda mažinant oro taršą.

\section{LITERATŪRA}

1. Higham A, Quinn AM, Cançado JED, Singh D. The pathology of small airways disease in COPD: historical aspects and future directions. Respir Res. 2019; 20(1):49.

2. Danila E, Zablockis R, Miliauskas S, Malakauskas K, Bagdonas K, Biekšienė K. Lètinès obstrukcinès plaučių ligos diagnostika ir gydymas. Vilnius: UAB „Vaistų žinios“; 2019. p. 27-9.

3. Singh D, Agusti A, Anzueto A, Barnes PJ, Bourbeau J, Celli BR et al. Global Strategy for the Diagnosis, Management, and Prevention of Chronic Obstructive Lung Disease: the GOLD science committee report 2019. Eur Respir J. 2019; 53(5). pii: 1900164.

4. Usmani OS. Choosing the right inhaler for your asthma or COPD patient. Ther Clin Risk Manag. 2019; 15:461-72.

5. Beeh KM, LaForce C, Gahlemann M, Wenz A, Toorawa
R, Fležar M. Randomised, double-blind, placebo-controlled crossover study to investigate different dosing regimens of olodaterol delivered via Respimat ${ }^{\oplus}$ in patients with moderate to severe persistent asthma. Respir Res. 2015; 16:87.

6. Buhl, R, Maltais, F, Abrahams, R, Bjermer, L, Derom E, Ferguson, G, et al. Tiotropium and olodaterol fixed-dose combination versus mono-components in COPD (GOLD 2-4). Eur Respir J. 45(4):969-79.

7. O'Donnell, DE, Casaburi R, Frith P, Kirsten A, De Sousa D, Hamilton A, et al. Effects of combined tiotropium/olodaterol on inspiratory capacity and exercise endurance in COPD. Eur Respir J. 2017; 49(4). pii:1601348.

8. Calverley PMA, Anzueto AR, Carter K, Grönke L, Hallmann C, Jenkins C, et al. Tiotropium and olodaterol in the prevention of chronic obstructive pulmonary disease exacerbations (DYNAGITO): a doubleblind, randomised, parallel-group, active-controlled trial. Lancet Respir Med. 2018; 6(5):337-44.

9. Dekhuijzen P, Vincken W, Virchow J, Roche N, Agusti A, Lavorini F, et al. Prescription of inhalers in asthma and COPD: Towards a rational, rapid and effective approach. Respir Med. 2013; 107(12):1817-21.

10. Iwanaga T, Tohda Y, Nakamura S, Suga Y. The Respimat ${ }^{\varpi}$ Soft Mist Inhaler: Implications of drug delivery characteristics for patients. Clin Drug Investig. 2019; 39(11):1021-30.

11. Iwanaga $T$, Kozuka $T$, Nakanishi J, Yamada $K$, Nishyama $O$, Sano H, et al. Aerosol Deposition of inhaled corticosteroids/ long-acting $\beta 2$-agonists in the peripheral airways of patients with asthma using functional respiratory imaging, a novel imaging technology. Pulm Ther. 2017; 3(1):219-31.

12. Ciciliani AM, Langguth $P$, Wachtel $\mathbf{H}$. In vitro dose comparison of Respimat inhaler with dry powder inhalers for COPD maintenance therapy. Int J Chron Obstruct Pulmon Dis. 2017; 12:1565-77.

13. Hochrainer D, Hölz H, Kreher C, Scaffidi L, Spallek M, Wachtel H. Comparison of the aerosol velocity and spray duration of Respimat Soft Mist inhaler and pressurized metered dose inhalers. J Aerosol Med. 2005 Fall; 18(3):273-82

14. Sustainable Development Unit. Pilot scheme for NHS Trusts Recycle inhalers through the Complete the Cycle scheme. 2019. Available at: https://www.sduhealth.org.uk/news/240/ pilotscheme-for-nhs-trusts--recycle-inhalers-through-thecompletethe-cycle-scheme 